\title{
Draft Genome Sequences of Two Brucella abortus Strains Isolated from Cattle and Pig
}

\author{
Narinder Singh Sharma ${ }^{1}$, Thakhur Sunita ${ }^{1}$, A K Arora ${ }^{1}$, Chandra Mudit ${ }^{1}$, Paviter Kaur ${ }^{1}$, Jagadesan \\ Sankarasubramanian², Udayakumar S Vishnu² , Paramasamy Gunasekaran², Jeyaprakash Rajendhran ${ }^{\circledR}$ \\ 1. Department of Veterinay Microbiology, Guru Angad Dev Veterinary and Animal Sciences University, Ludhiana -141 004, Punjab.India. \\ 2. Department of Genetics, School of Biological Sciences, Madurai Kamaraj University, Madurai-625021, Tamil Nadu, India.
}

$\triangle$ Corresponding author: Jeyaprakash Rajendhran, Department of Genetics, School of Biological Sciences, Madurai Kamaraj University, Madurai-625021, Tamil Nadu, India. Email: jrajendhran@gmail.com

(c) 2015 Ivyspring International Publisher. Reproduction is permitted for personal, noncommercial use, provided that the article is in whole, unmodified, and properly cited. See http://ivyspring.com/terms for terms and conditions.

Published: 2015.10.25

\begin{abstract}
We report the draft genome sequences of two Brucella abortus strains LMN1 and LMN2 isolated from cattle and pig. The LMN1 and LMN2 have the genome size of 3,395,952 bp and 3,334,792 bp, respectively. In addition to the conserved genes of Brucella, few novel regions showing similarity to the phages were identified in both strains.
\end{abstract}

Key words: genome sequence, Brucella abortus

Brucella species are small, non-motile, facultative, intracellular, Gram negative, coccobacilli (1). Members of Brucella cause a zoonotic disease brucellosis which is endemic in many areas throughout the world, causing chronic infections with common outcomes being abortion and sterility in infected animals (2). Brucella species are designated based on their host preferences. Cattle are the preferred host of Brucella abortus and the economic importance attributed to bovine brucellosis (1). B. abortus induces spontaneous abortion in cattle and causes economic and industrial loss. Brucella infection was treated with a combination of antibiotics. Though, in its chronic phase, eradication is difficult since Brucella spp. are intracellular pathogens, which puts them out of reach of humoral immunity and several antibiotics (3). Hence, whole genome sequencing and genome analysis will help in unravelling the mystery behind brucellosis. Here, we present the draft genome sequence of two strains (LMN1 and LMN2) and its annotation.

We isolated two B. abortus strains designated LMN1 and LMN2 from cattle and pig. Genomic DNA of both the strains was isolated using DNeasy kit (Qiagen, Hilden, Germany). The 16S rRNA sequence of these strains showed $100 \%$ similarity with all Brucella species. Therefore, species identification was performed by multi locus sequence analysis (MLSA) with 9 loci as previously described (4). The genome was sequenced using an Ion Torrent personal genome machine (Life Technologies, Carlsbad, CA). De novo assembly was performed using MIRA (Mimicking Intelligent Read Assembly) version 3.9.18 (5). The genome sequences were annotated using the RAST (Rapid Annotations using Subsystems Technology) server (6) and NCBI Prokaryotic Genomes Annotation Pipeline (http://www.ncbi.nlm.nih.gov/genome/ annotation_prok/process/). The genome sequence and assembly information of each strain is summarized in Table 1. In total, 3,431 genes were predicted in B. abortus LMN1, of which 3,373 were protein-coding genes (encoding 2,603 functional and 770 hypothetical proteins), whereas $B$. abortus LMN2 contains 3,358 genes, of which 3,301 were predicted protein-coding sequences (encoding 2,582 functional 
and 719 hypothetical proteins). The rRNAs and tRNAs genes were predicted using RNAmmer (7) and tRNAscan-SE 1.21 (8) respectively. B. abortus LMN1 contains 58 RNA genes (52 tRNAs and 6 rRNAs genes) and B. abortus LMN2 has 57 RNA genes (52 tRNAs and 5 rRNAs genes).

In $B$. abortus LMN1, $\sim 60 \mathrm{~kb}$ of novel region was identified, which encodes 57 genes (13 functional proteins and 44 hypothetical proteins). This region showed 73\% identity with Roseobacter phage. Similarily, in B. abortus LMN2 $\sim 9.5 \mathrm{~kb}$ of novel region was identified, which encodes 5 genes ( 3 conserved mega phage proteins and 2 hypothetical proteins) showed $67 \%$ identity with Sinorhizobium meliloti phage. In addition, a Brucella phage $(\sim 59 \mathrm{~Kb})$ was observed in both
B. abortus LMN1 (contig 15) and B. abortus LMN2 (contig 20). This region showed 91\% similarity with Brucella phage genome. Further comparative genome analysis between these strains and other Brucella strains will help in understanding host adaptation and bacterial microevolution.

\section{Nucleotide sequence accession numbers}

The draft genome sequences of the Brucella abortus strains LMN1 and LMN2 have been deposited in DDBJ/EMBL/GenBank under the accession numbers JPHM00000000 and JPHL00000000, respectively. The versions described in this paper are JPHM01000000 and JPHL01000000.

Table 1 Sequencing and assembly statistics for the two strains of Brucella abortus

\begin{tabular}{|c|c|c|c|c|c|c|c|c|c|}
\hline Strain & $\begin{array}{l}\text { Total se- } \\
\text { quenced } \\
\text { bases }(\mathrm{Mb})\end{array}$ & $\begin{array}{l}\text { Total } \\
\text { reads }\end{array}$ & $\begin{array}{l}\text { Fold } \\
\text { coverage }\end{array}$ & $\begin{array}{l}\text { Average read } \\
\text { length }(\mathrm{bp})\end{array}$ & $\begin{array}{l}\text { Total con- } \\
\text { sensus (bp) }\end{array}$ & $\begin{array}{l}\text { No. of } \\
\text { contigs }\end{array}$ & $\begin{array}{l}\text { Largest } \\
\text { contig (bp) }\end{array}$ & $\begin{array}{l}\text { GC con- } \\
\text { tent }(\%)\end{array}$ & $\begin{array}{l}\text { Accession number } \\
\text { at NCBI }\end{array}$ \\
\hline B. abortus LMN1 & 388.2 & $1,907,540$ & $117 X$ & 196 & $3,395,952$ & 24 & 971,337 & 57.2 & JPHM00000000 \\
\hline B. abortus LMN2 & 279.68 & $1,209,634$ & $75 X$ & 200 & $3,334,792$ & 25 & 685,937 & 57.2 & JPHL00000000 \\
\hline
\end{tabular}

\section{Acknowledgements}

The work was financially supported by the Department of Biotechnology, Govt. of India under DBT-Network Project on Brucellosis. Authors also acknowledge the UGC-CAS, UGC-CEGS, UGC-NRCBS, DBT-IPLS and DST-PURSE programs of SBS, MKU.

\section{Competing Interests}

The authors have declared that no competing interest exists.

\section{References}

1. Corbel MJ. Brucellosis: an overview. Emerg Infect Dis. 1997; 3: 213-221.

2. Wattam AR, Williams KP, Snyder EE, Almeida NF Jr, Shukla M, Dickerman AW, Crasta OR, Kenyon R, Lu J, Shallom JM, Yoo H, Ficht TA, Tsolis RM, Munk C, Tapia R, Han CS, Detter JC, Bruce D, Brettin TS, Sobral BW, Boyle SM, Setubal JC. Analysis of ten Brucella genomes re- veals evidence for horizontal gene transfer despite a preferred intracellular lifestyle. J Bacteriol. 2009; 191: 3569-3579.

3. Roop RM, Bellaire BH, Valderas MW, Cardelli JA. Adaptation of the brucellae to their intracellular niche. Mol. Microbiol. 2004; 52: 621-630.

4. Whatmore AM, Perrett LL, MacMillan AP. Characterization of the genetic diversity of Brucella by multilocus sequencing. BMC Microbiol. 2007; 7: 34 .

5. Chevreux B, Wetter T, Suhai S. Genome Sequence Assembly Using Trace Signals and Additional Sequence Information, In Computer Science and Biology: Proceedings of the German Conference on Bioinformatics (GCB). Research Centre for Biotechnology (GBF), Braunschweig, Germany. 1999; 99: 45-56.

6. Aziz RK, Bartels D, Best AA, DeJongh M, Disz T, Edwards RA, Formsma K, Gerdes S, Glass EM, Kubal M, Meyer F, Olsen GJ, Olson R, Osterman AL, Overbeek RA, McNeil LK, Paarmann D, Paczian T, Parrello B, Pusch GD, Reich C, Stevens R, Vassieva O, Vonstein V, Wilke A, Zagnitko O. The RAST Server: Rapid Annotations using Subsystems Technology. BMC Genomics. 2008; 9: 75.

7. Lagesen K, Hallin P, Rodland EA, Staerfeldt HH, Rognes T, Ussery DW. RNAmmer: consistent and rapid annotation of ribosomal RNA genes. Nucleic Acids Res. 2007; 35: 3100-3108.

8. Lowe TM, Eddy SR. tRNAscan-SE: a program for improved detection of transfer RNA genes in genomic sequence. Nucleic Acids Res. 1997; 25: 955-964. 